Año LXXXI. urtea $278-2020$

Septiembre-diciembre Iraila-abendua

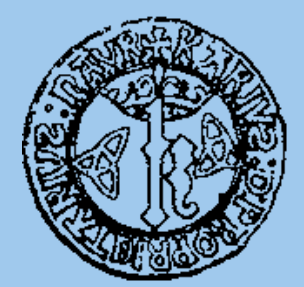

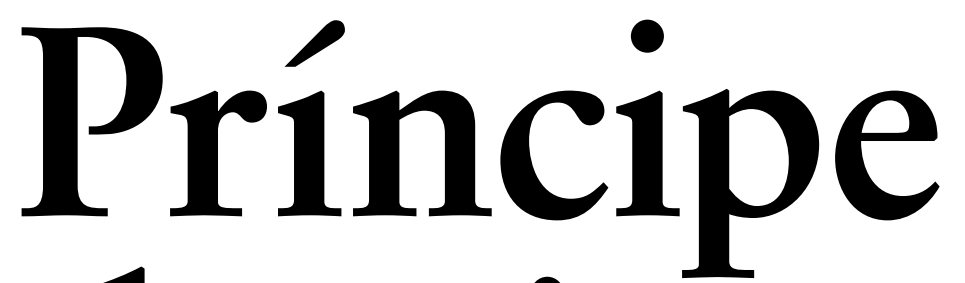

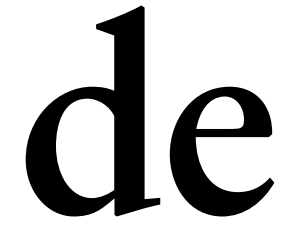
Viana

SEPARATA

\title{
Gustav Henningsen, un encendido asombro ante la realidad
}

Mikel AZURMENDI INCHAUSTI

\footnotetext{
Gobierno $\stackrel{\text { (i) }}{=0}$ Nafarroako de Navarra 40 Gobernua
} 


\section{Sumario / Aurkibidea}

\section{Príncipe de Viana}

Año LXXXI - n. ${ }^{\circ} 278$ - septiembre-diciembre de 2020

LXXXI. urtea - 278. zk. - 2020ko iraila-abendua

\section{GUSTAV HENNINGSEN / MARISA REY-HENNINGSEN}

Homenaje / Omenaldia

Ignacio Panizo (coord./koord.)

Vol. I. lib.

Preámbulo / Hitzaurrea

Rebeca Esnaola Bermejo

Presentación / Aurkezpena

$\underline{\text { Ignacio Panizo Santos }}$

\section{TRAYECTORIA VITAL E INTELECTUAL DE GUSTAV HENNINGSEN \\ Y MARISA REY-HENNINGSEN / \\ GUSTAV HENNINGSENEN ETA MARISA REY-HENNINGSENEN \\ BIZITZA ETA IBILBIDE INTELEKTUALA}

Autobiografía de Gustav Henningsen

Autobibliografía de Gustav Henningsen

Bibliografía de Marisa Rey-Henningsen

Transcribiendo a Gustav y Marisa

Candela M. Camiño López

Gustav Henningsen, un encendido asombro ante la realidad

Mikel Azurmendi Inchausti

El danés peligroso. Semblante humano de Gustav Henningsen.

Evocación a cuatro manos

Jean Pierre Dedieu, Gunnar W. Knutsen

«Un danés peligroso» en los fondos del Archivo Histórico Nacional

Jaime Contreras Contreras 


\section{Sumario / Aurkibidea}

Gustav Henningsen: del antropólogo al historiador (pasando por archivero)

Juan Ignacio Pulido Serrano

Gustav Henningsen y Marisa Rey-Henningsen, folcloristas daneses en Galicia, 1965-1977 (entre magnetófonos y cuentos matriarcales)

José Manuel Pedrosa Bartolomé

Marisa Rey-Henningsen y el arte de la traducción de la literatura danesa José Luis Garrosa Gude

OBRA DISPERSA DE GUSTAV HENNINGSEN /

GUSTAV HENNINGSENEN OBRA BARREIATUA

Los documentos de Alonso de Salazar Frías. Una polémica sobre la brujería en España, 1610-1614

Gustav Henningsen

De la caza de brujas al culto de brujas

Gustav Henningsen

Archivos e historiografía de la Inquisición española

Gustav Henningsen

El síndrome de brujería infantil: el abuso infantil satánico contemporáneo

y los procesos por brujería infantil de antaño

Gustav Henningsen

999

La brujería y la Inquisición

Gustav Henningsen

Enciclopedia de la brujería

Gustav Henningsen

El vuelo de las brujas y los inquisidores españoles o cómo explicar lo imposible

Gustav Henningsen

Currículums

Analytic Summary

Normas para la presentación de originales / Idazlanak aurkezteko arauak /

Rules for the submission of originals 


\section{Gustav Henningsen, un encendido asombro ante la realidad}

Gustav Henningsen, harridura bizi bat errealitatearen aitzinean

Gustav Henningsen, an burning amazement at reality

Mikel Azurmendi Inchausti ${ }^{\dagger}$

Profesor de Antropología Social

DOI: https://doi.org/10.35462/pv.278.6 


\section{RESUMEN}

El artículo repasa la dilatada trayectoria intelectual de Gustav Henningsen desde sus inicios en Dinamarca como folclorista hasta su consagración mundial como uno de los mayores expertos en los campos de investigación de la brujería y de la Inquisición española, sin olvidar su fase intermedia como etnólogo por la Galicia rural. Traza su evolución intelectual y señala los resultados conseguidos en el estudio del famoso proceso de fe contra las brujas del Baztan en el siglo XVII.

Palabras clave: Inquisición; brujería; Navarra; inquisidor Salazar y Frías; etnografía.

\section{LABURPENA}

Artikuluak Gustav Henningsenen ibilbide intelektual luzea azaltzen du; nola Danimarkan folklorista gisa hasi zen eta nola, sorginkeriaren eta Inkisizio espainiarraren ikerketa-alorretan, munduko aditu handienetako bat bihurtu zen; ahantzi gabe tarteko aldi batean etnologo gisa jardun zuela Galiziako landa-eremuan. Haren ibilbide intelektuala deskribatzen du, eta adierazten, zer-nolako emaitza bikainak lortu zituen XVII. mendeko Baztango sorginen fede-prozesu entzutetsuaren azterlanean.

Gako hitzak: Inkisizioa; sorginkeria; Nafarroa; Salazar y Frías inkisidorea; etnografia.

\section{ABSTRACT}

The article reviews Gustav Henningsen's long intellectual career from its beginnings as a folklorist in Denmark to his worldwide recognition as one of the greatest experts in the research fields of witchcraft and the Spanish Inquisition, without forgetting his intermediate time as an ethnologist in rural Galicia. It traces his intellectual evolution and highlights the results achieved in the study of the famous faith trial against the witches of Baztan in the 17 th century.

Keywords: Inquisition; Witchcraft; Navarre; Inquisitor Salazar y Frías; Ethnography. 
1. LA ADMIRACIÓN COMO COMIENZO DE UN HOMBRE (1959-1964). 2. O HOME QUE VIVE DOS CONTOS (1965-1968). 3. EL HOMBRE QUE HIZO HABLAR A ARCHIVOS ARCANOS (1969-1973). 4. EL HOMBRE QUE ACLAMÓ A UN INQUISIDOR Y SU JUSTICIA. 5. EL HOMBRE QUE INTERPRETÓ DE NUEVO MODO LOS HECHOS DE PERSECUCIÓN BRUJERIL. 6. EL HOMBRE QUE DESCORRIÓ LA CORTINA QUE CUBRÍA A LA INQUISICIÓN. 7. LISTA DE REFERENCIAS.

He hablado con Goethe. ¡Hermano! Es el más bello placer de nuestra vida encontrar tanta humanidad en tanta grandeza.

Carta de Hölderling a Hegel 26/01/1795

\section{LA ADMIRACIÓN COMO COMIENZO DE UN HOMBRE (1959-1964)}

El arrobo de Hölderling ante Goethe se debía a que lo admiraba. Era la excelencia de Goethe la que le ponía en sintonía pues ya sabemos que en gran estima se tiene del otro aquello que uno es o se propone ser. Gustav Henningsen admiraba desde muy temprano a Julio Caro Baroja.

En 1957, a los veintiún años, un estudiante danés en pantalón vaquero y jersey islandés, loco por el mundo de los cuentos de Andersen, preguntaba en Copenhague por Caro Baroja a su joven mujer española. Esta, que recién llegaba de educarse en Londres y desconocía bastante lo que no fuese literatura, solo podía hablarle de las teorías e investigaciones sobre el Romancero español de Menéndez Pidal. Pero bien pronto, en cuanto ambos pisaron Madrid, ella obtuvo mediante un pariente cercano que Gustav pudiera acercarse hasta don Julio. Algo existía en ambos que iba a unificar su destino. Unos dirán que Caro Baroja y Henningsen comparten el gusto por lo antañón, otros lo sustantivarán en legajos y asuntos viejos. Efectivamente, aun siendo ambos hombres de archivo, buscadores de lo recóndito, también comparten presencia activa en el mundo de la oralidad del campesino vivo. Yo creo empero que en la raíz que ha fraguado co- 
mún destino hay algo tan ínsito a la inteligencia humana como el asombro. Un pasmo ante la intemperie en que se hallaban antecesores nuestros en tiempos pasados. Por esa fascinación empezaron ambos acercándose al habla y costumbres del vilipendiado pueblo llano, siendo enseguida empujados a buscar y escrutar documentos antiguos y papeles inquisitoriales hasta conocer la verdad de la inclemente existencia personal en la cultura que nos precedió.

La admiración comienza en el asombro cuando algo inusitado y sorprendente «contradice nuestra experiencia pasada» aseguraba Spinoza, sabedor de que el comienzo del pensamiento occidental -allá, en Grecia- fue la toma de conciencia de lo asombroso, el pasmo ante lo inesperado. Thaumatsein lo llamaba Aristóteles. Cuando el joven vuela de su nido por primera vez para pensar por cuenta propia, se da de bruces con la realidad. Al salir de lo doméstico, todo le es desacostumbrado y lo que más contradiga a su sentido común le hará preguntas. Hacérselas y tratar de responderlas es plantar cara a la realidad descubriendo sus entrañas. Asombrarse y admirar, un mismo acto verbal para Aristóteles, del cual arranca la lengua castellana la voz taumaturgo, hacedor de cosas admirables.

La vida de Henningsen podría constituirse en un emblema de ese aserto aristotélico sobre los hombres abiertos al mundo, los únicos que por sintonizar su inteligencia con lo real descubren nuevos mundos. Es decir, nuevas maneras de comprenderlo. Comenzaré dando unos botones de muestra.

Maravillado ante los cuentos de H. C. Andersen, el veinteañero Henningsen se zambulló en las tradiciones populares hasta preparar junto con otros dos estudiosos un registro bibliográfico, el cual se publicó más tarde en dos tomos como Bibliografía sobre Cultura Popular danesa (Henningsen, Holbek \& Rasmussen, 1960, 1963-1964). Luego se propuso ahondar a lo Menéndez Pidal en el cuerpo de creencias de aquella narrativa, pese a la dificultad de que tanto los cien romances épicos recogidos por Vedel como los otros cien recogidos por Syv se hallasen muy desperdigados en quince o más ediciones y en muy diferentes versiones editadas a lo largo de más de doscientos años. Henningsen dedicó tres años de investigación para proponer la que pudiese ser la versión comentada del romancero danés. Su investigación la plasmó en el artículo «Vedel, Syv y sus impresores. Un estudio bibliográfico» (Henningsen, 1959). Publicado en la revista de Estudios Daneses como hito en el romancero patrio, había sido elaborado merced a ir robando horas al respiro y al sueño ya que, a la vez, trabajaba profesionalmente como contratado en el Archivo Real de la capital.

Estupefacto ante la afirmación de un escritor norteamericano de que algo tan ínsito en el pueblo como el relato humorístico del «vamos a contar mentiras, tra-la-ra» únicamente se diese en su país y no en Europa -a excepción de los célebres cuentos Las mentiras del Barón de Münchhausen-, había emprendido a la vez una investigación con trabajo de campo incluido. Su objeto era aportar una confirmación de la existencia de una narrativa oral sobre patrañas marineras. De entrada, publicó en un diario su primer artículo: un relato sobre el buque fantasma que escuchó a un viejo marino propietario del barco "Albatros», así apodado también él mismo (Henningsen, 1958). Desde su 
departamento de archivero había escrito en los periódicos del país solicitando de los lectores cuentos de mentiras marineras. Le llovieron relatos y viejos dichos y hasta de la revista del museo noruego de Tönsberg le llegaron preciosos botones de muestra. Fruto del trabajo fueron Historias marineras, publicadas en la revista de los astilleros Skibet, y también «El arte de mentir perpendicularmente». Este artículo fue traducido al inglés unos años después en una publicación de la universidad americana de Indiana ${ }^{1}$. La investigación hizo que su nombre se inscribiera en la germana Encyklopädie des Märchens pero a él, aquel trabajo de campo le abrió un mundo sorprendente. Hallándose personado en la isla danesa Aerö investigando entre sus habitantes sobre la naturaleza de la tradición marinera, le dejó estupefacto el hecho de que dos hermanas le informasen sobre una paisana que «no salía jamás a pasear con su bebé sin llevar una bolsita de sal y un trozo de pan de centeno debajo del colchón, por si una bruja pasase y la mirase $»^{2}$. Así se dio de bruces con supervivencias brujescas.

Así es como Henningsen decidió transformar su proyecto de recogida de datos sobre el mundo tradicional en una investigación académica sobre las creencias en brujas en la parroquia rural de Marstal de esa misma isla. Para su recopilación fue contactando con un centenar de personas, cuyo "saber» se remontase a algo más de un siglo. En el listado de personas se consignaba si cada una de ellas creía o no en brujas. El sistema de relaciones le llevó a determinar linajes o familias sobre las que pendía una peyorativa acusación brujeril. Entonces indagó en los archivos, que ya le eran familiares, llegando a pergeñar árboles genealógicos de persecución hasta el siglo XVIII. A causa de esta información confidencial decidió no hacer pública su investigación «Análisis estructural de las creencias en brujas en una comunidad danesa» ${ }^{3}$. Un diario de la ciudad sí se hizo eco de esa tesina ${ }^{4}$ con la que obtuvo, en 1962, el título universitario de licenciatura o Magister Artium. Ya titulado, pudo acceder al puesto de archivero oficial e investigador en el Dansk Volkemindesamling. Tenía veintiocho años y debía hacer un alto para el servicio militar en la espera de su primer hijo. Fue un tiempo de meditar hacia dónde dirigir su investigación doctoral.

$\mathrm{Al}$ año siguiente tuvo que suplir en la universidad a su catedrático de Folklore y una circunstancia insospechada le clarificó la dirección investigadora. La ocasionó la «inspiradora conferencia» de un profesor irlandés sobre la brujería en su país, donde apenas había existido persecución. Perplejo ante la sintonía entre puntos de vista de aquel

1 Henningsen (1960 y, sobre todo, 1961). Su traducción inglesa (Henningsen, 1965a). También publicó (Henningsen, 1965b).

2 Henningsen (2010, p. 425). Este artículo es una adaptación al español de su propuesta autobiográfica en danés, depositada en los Archivos del Reino con motivo de la imposición de la cruz de "Caballero de Dannebrog» por la reina Margarita II, en julio de 2002.

3 Aunque hoy la tesina prosigue sellada, el lector que precise más información sobre aquel primerizo estudio de «recogida» de creencias populares brujescas, hará bien en consultar la ponencia que desarrolló Henningsen en el XI congreso de la International Society for Folk Narrative Research (1995, january 6-12, Mysore, India). En ella se perfila con claridad la pauta folklórica de la metodología que profesaba, con la única especificidad de distinguir tradición/uso-de-tradición basada en la distinción del lingüista Hjemslev entre langue/parole. Como en breve se comprobará, el propio Henningsen se apercibió bien pronto de esas limitaciones metodológicas.

4 Politiken, 17/06/1962. 
profesor y los de su trabajo de campo, sustituyó su proyecto de brujería autóctona por otro comparativo en Irlanda, País Vasco y la comunidad danesa de Aerö. Aprovechó sus vacaciones en España para volver a contactar con Caro Baroja, pero este le desaconsejaba el estudio en el País Vasco dirigiéndole hacia Galicia, donde las tradiciones eran más vivas. Le sugería también que el desconocimiento del euskera supondría una seria desventaja.

Es un hecho que a Henningsen no lo quiso cerca suyo Caro Baroja, pero es incuestionable que sí satisfizo a todas las cuestiones que le planteaba el joven "archivero danés» ${ }^{5}$ en las diferentes ocasiones en que este acudió a él. En una de ellas hasta tuvieron que acudir a un informante de Caro Baroja, médico de San Sebastián, el cual había mentado una reunión-conventículo tenida en algún caserío durante los años 40 y que Caro Baroja la había interpretado como hecho brujeril. A Henningsen no le cuadraba esta noticia de Las brujas y su mundo, pero todo se aclaró en cuanto aquel médico especificase que podría haberse tratado de una ceremonia vudú, a las que se habría habituado en América aquel etxekojaun, un indiano vuelto a su tierra. También Henningsen había rectificado a Caro Baroja sobre el número inicial de presos de Zugarramurdi en las mazmorras de Logroño, y eso en su primer artículo sobre brujería en España, en 1979. Seguramente esos fuesen algunos de los motivos por los que Don Julio clamase «contra varios inquisidores a la moderna ${ }^{6}$. El luterano Henningsen tomó la alusión a su persona con tanta benignidad por saberse equivocadamente nombrado por quien él tanto admiraba que, en su autobiográfica semblanza para los archivos de la reina danesa, se presentaba a sí mismo de manera harto irónica como un «inquisidor a la moderna, de raza nórdica». Tanto lo admiraba Henningsen que en esa misma semblanza, ya a las puertas de la vejez, dejó escrito: «En caso de considerarme alumno de alguien, lo sería de Caro Baroja» ${ }^{7}$.

Dispuesto, pues, a hacer una tesis doctoral comparativa basada en un trabajo de campo sobre la brujería en Dinamarca, España e Irlanda, ahí lo tenemos en A Coruña interior en medio de un vecindario de aldea perdida y todavía sin energía eléctrica. Como se comprobará, aquel estupor de haber coincidido con los resultados conceptuales de un profesor irlandés lo tiene todavía a Henningsen amarrado de cuerpo y alma. Enseguida le conducirá a los archivos inquisitoriales en busca de antiguos procesos

5 Así lo llamaba don Julio con cierto soniquete cuando en las veraniegas visitas a Itzea elucubrábamos sobre la impresionante documentación compilada por el inquisidor Salazar. A ella había llegado increíblemente Henningsen en 1968 antes que nadie, pues sabido es que H. Ch. Lea jamás había pisado el Archivo de Simancas, ni tan siquiera suelo español, ya que a cambio de generosos dólares a los archiveros, había ido recibiendo miles de trascripciones de viejos documentos. Así es como escribió su afamada Historia de la Inquisición.

6 Caro Baroja (1986, p. 66) se lee: «Por otra parte, también he de admitir que durante mi vida he tratado por lo menos sufrido, a varios inquisidores a la moderna. No todos hispánicos y católicos sino también nobles representantes de las razas nórdicas o de la raza de Israel, los cuales han fiscalizado mis escritos y hasta mis actos». Para la referida rectificación a don Julio véase Henningsen (1979, nota 48).

7 Henningsen (2010, p. 428). Muy extraña resulta esa benignidad en un intelectual a tenor de lo que se estila en nuestros días, tal como ha dejado sentado quien considero uno de los más agudos pensadores actuales en España: «Los intelectuales [...] somos buenos en ver la paja en el ojo ajeno. Amamos la verdad si nos sirve para destruir la verdad del otro y armarnos de superioridad moral» (Félix Ovejero, El Mundo, 30/01/19). 
judiciales de brujos en Galicia y, bien pronto, a la más importante documentación en Occidente sobre la persecución de la brujería. Quien lo conozca puede asegurar que aun hoy prosigue soñando con un elenco de investigaciones sobre la Inquisición. Pero los que le admiramos sabemos que esa tarea se la deja a otros.

Hablemos, pues, de las tareas que emprendió en 1965 y de las que culminó, no sin antes dejar aquí apuntado que esa misma prontitud cognitiva a reaccionar ante lo inusual y extraordinario - una cualidad que he llamado admiración y es fruto de cierta "pureza de corazón»-, lo había dejado tan pasmado ante una estudiante española que casó de inmediato con ella, hecho que lo afincó en España y lo convirtió en afamado hispanista. Casados y ya ancianos prosiguen en la existencia, ahora en Copenhague cerca de sus cuatro hijos, tras haber abandonado su larga estancia en tierras andaluzas.

\section{O HOME QUE VIVE DOS CONTOS (1965-1968)}

En un reportaje de un diario gallego se publicaba en $1968^{8}$ la fotografía de un «joven intelectual danés (que) causó una profunda impresión» en el periodista. Este había anunciado a grandes caracteres «becado por la universidad de Copenhague». Debajo, iba con una caja algo menor la noticia «Lleva tres años estudiando las ancestrales costumbres de Galicia». Y entre comillas iba un tercer título, esta vez puesto en boca de aquel joven intelectual «Los gallegos no son más supersticiosos que los daneses». Cualquier lector de comic hubiese dicho que aquel joven de la foto era el mismo Clark Kent con grandes gafas de moldura redonda negra, venido a una granja de Kansas desde un planeta lejano y con poderes especiales, un tal Superman. Es realmente extraña la semejanza del treintañero Gustav Henningsen con él, al menos para los familiarizados con cierta cultura cinéfila, que de leer hoy esa antigua página del diario gallego podríamos decir que acaso se tratase del otro lozano y bonachón Christopher Reeve, que en repetidas películas actuó de Supermán. Quienes hemos conocido a Henningsen de candoroso hombre maduro, muy madurado entre viejos pliegos de papel, ganamos mucho en saber que también fue el mocetón de buen ver y muchas ansias de ver mundo y comprenderlo que adivinamos en esa foto.

Aquel danés, al que se presentaba en el diario como especializado en etnología, anunciaba tener «más de doscientas horas grabadas en cintas magnetofónicas con historias, canciones y las más raras costumbres gallegas. También tengo una colección de más de 2000 fotografías hechas por mí». Cincuenta años después de aquel reportaje, otro diario gallego ${ }^{9}$ se hacía eco en 2015 de la inauguración en el Museo do Povo Galego de una selección de aquel material fotográfico, ya digitalizado tras el tratamiento de los negativos. La selección concernía al territorio donde se centró su trabajo de campo, el entorno de Ordes, parroquia de Ardemil. La exposición titulaba la muestra de más de cien fotografías como Galicia máxica, reportaxe dun mundo desaparecido (1965-

8 Faro de Vigo, 7/02/1968, p. 7, José Ramón.

9 La Voz de Galicia, 27/11/2015, Santiago L7, «Ordes y su pasado de tradición y brujería», P. Calveiro. 
$1968)^{10}$. Con un título o comentario a cada fotografía, todas estaban organizadas en nueve secciones que, repartidas en salas distintas, iban siendo recreadas por algunas de las antañonas grabaciones registradas por Henningsen. Por estar en gallego, la mayoría de las ciento cinco horas de grabación habían interesado mucho al Instituto da Lingua Galega de la Universidad de Santiago de Compostela. Tanto gustaron que elaboró un proyecto de procesamiento de aquellos documentos sonoros y creación de una base de datos, que posibilitara hallar cualquier voz o expresión popular incluida en ellos. Los transcriptores de textos de voz que presentaban dicho catálogo lo calificaban de «El tesoro de Gustav Henningsen» ${ }^{11}$.

Muchas debieron de ser y no siempre fáciles las horas de charla con los vecinos a tenor no solo de ese caudal de información registrada sino del apodo con el que aquel extranjero era conocido en aquellas tierras: «el hombre que vive de los cuentos». Todo lo quería saber, siempre rogando de mil modos diferentes que se lo contaran todo. Fueron casi dos años de horas de charla, que no debieron de ser nada fáciles, según colegimos de ese informe de $1969^{12}$, donde se señala explícitamente la diferencia de acogida de los campesinos y marineros daneses y esta otra de los gallegos. Estos, al comienzo, lo tomaron "por espía, por policía secreta y hasta hubo quien corrió la voz de que yo era un extranjero que quería hablar mal de España en los periódicos de mi país». A causa de rumores de este percal hasta hubo de suspender una provechosa fuente de investigación al noveno día de estancia en la isla de Ons.

El informe sobre el trabajo de campo realizado por aquel universitario becado está lleno de enigmas que podrían ser a su vez objeto de investigación doctoral. Enumeraré el punto que mayor perplejidad me ha evocado su lectura. Se trata de la vacilación de Henningsen ante su propio trabajo de campo pues flotan, implícitas, preguntas tales como ¿qué estuve haciendo durante el período de recogida de datos, un trabajo de antropología social o de folklore?, ¿qué forma narrativa daré a estos elementos culturales todavía vivos que he recogido? Conviene entender que Henningsen partía con la visión académica del folklore como ciencia: un ir coleccionando textos orales antiguos atribuidos a un colectivo, el pueblo. Se podría decir que su objeto era compilar «supervivencias» de creencias en tres sociedades alejadas entre sí a fin de compararlas en base a sus funciones de justificación social de las conductas. La brujería podría condensar un núcleo de significado en tanto que creencia en lo sobrenatural (sic) actuando a modo de fósil del pensamiento humano más primitivo. Por consiguiente, se trataba de dar con los «mejores» informantes, buscados siempre bajo el criterio de quién ofrecía la máxima cantidad y más completos textos. Este supuesto teórico es una implícita

10 Henningsen (2015) hermoso catálogo de 257 páginas que, merced al patrocinio de la Deputación de A Coruña, daba cuenta de la exposición. Contenía además varios interesantes artículos que la contextualizaban, entre ellos se halla el informe que, en 1969, envió Henningsen a la Universidad de Copenhague como colofón de su itinerario intelectual y trabajo de campo. El catálogo no contiene las grabaciones que en la exposición contribuían a recrear el cuadro sociocultural de las fotografías.

11 S. Vázquez Núñez y X. Sousa, «O tesouro de Gustav Henningsen» en Henningsen (2015, pp. 45-47).

12 Henningsen (1969, pp. 20-31). Este informe también fue publicado en 1971 -traducción de Marisa Rey-Henningsen- (Henningsen, 1971). 
confesión de que no todas las personas del pueblo comparten el mismo grado de «saber popular». Tal es una de las paradojas del folklore entendido como conocimiento porque apunta al dilema: o no todos «los del pueblo» poseen los mismos arrestos para producir conducta social unificada o bien las creencias son eso, nada más que creencias. Sin embargo, poco antes de iniciar ese trabajo de campo en Galicia, aquel estudioso del folklore danés había tenido la enorme fortuna de pasar catorce días en algunas aldeas de Pontevedra acompañando a Carmelo Lisón Tolosana, a la sazón a punto de acabar su trabajo de campo en Galicia. Lisón le inició en el oficio etnográfico de preguntar, puesto que el folklorista únicamente recoge, a ser posible sin preguntar. Ya se sabe que la respuesta pende siempre de la pregunta, la cual va impregnada siempre de dirección; la de Lisón conducía a cierto estructural-funcionalismo y de su recogida sobre el terreno salió un artículo seminal: una descripción densa de los aspectos expresivos, cognitivos, rituales y simbólicos de la parroquia gallega, presentada como una unidad moral con estructura real, ideal y simbólica, o sea, como una integración con diferentes niveles ${ }^{13}$. Henningsen, que todavía conserva dos decenas de grabaciones que registró a Lisón en aquella ocasión, cobró conciencia de que no era suficiente su aprendizaje de folklorista, muy pegado -en tanto que danés- a la teoría del lingüista Hjelmslev. Lo dice él mismo en el informe: «tuve que liberarme de los métodos filológicos que dominaban la enseñanza recibida durante mis estudios folklóricos. Comprendí que mi primordial objeto como investigador de las creencias populares tenía que ser lo que la gente hace y piensa, no lo que dice» (estos tres últimos verbos iban subrayados por él). O sea, borraba de su mente el primordial concepto de "supervivencia» de ciertas creencias primitivas como supuesto motor de similares estilos de vida a través del tiempo y del marco social. De esta manera se le derrumbaba también la finalidad comparatista de su investigación que, en el fondo, le originó cierta concepción histórico-geográfica.

Ahí lo tenemos, cariacontecido pero tenaz, intentando durante casi dos años en el entorno de aldeas de la parroquia de Ardemil hacerse con un modo de pensar etnográfico y sirviéndose de grabaciones e imágenes «como base para hacer en mis entrevistas preguntas complementarias» a lo que le hubiesen dicho. Es decir, sirviéndose de las imágenes visuales y sonoras para pensar más él mismo y acercarse a mejores preguntas. Ahí lo tenemos, postrado en admiración del saber antropológico tras haber escuchado y visto actuar in situ a un auténtico maestro. «Estoy convencido de que los folkloristas tenemos mucho que aprender de la escuela de antropología social» añadía en ese informe a la universidad danesa y citaba ese "para mí muy inspirador» artículo de Lisón Tolosana ${ }^{14}$. Era en 1969 cuando firmaba Henningsen ese su informe final y por entonces mismo acababa de publicarse el artículo de Lisón, que fue leído con avidez

13 Lisón (1969, pp. 101-151), artículo que más tarde, constituyó el capítulo 5. e de Lisón (1976).

14 Disculpará el lector este alto a pie de página para, tout en passant, rendirle un agradecido homenaje a Carmelo Lisón Tolosana -fallecido durante la pandemia Covid-19- por lo que supuso para nosotros, los de la «Antropología sin fronteras», sin que lo hayamos podido despedir.

Personalmente me honra haberles reunido como ponentes a Gustav Henningsen y Carmelo Lisón -y curiosamente también al organizador del presente homenaje, Ignacio Panizo- en la semana de reflexión sobre Inquisición y brujería. El Auto de fe de Logroño de 1610 con motivo del 400 aniversario del Auto de fe. Fue un simposio que organicé en Logroño bajo los auspicios de su Ayuntamiento y el Instituto de Estudios Riojanos. 
por Henningsen. Sin poder añadir nada al punto de vista de Lisón, solo cabía asimilarlo e «inspirarse» en él. Pero lo comunica a la comunidad académica con la humildad de quien se ha propuesto avanzar en el saber. Lo hace en un significativo apartado «Folklore y Antropología social» planteando una especie de revisión general de los estudios de folklore (Henningsen, 1971, pp. 71-72):

¿Cómo podríamos definir los elementos más pequeños de las creencias populares? ¿Podemos estudiar las creencias populares, entendiendo por tales un complejo de ritos, mitos y creencias, como una rama natural o traería esta disgregación problemas metodológicos? En lo que a los etnólogos escandinavos se refiere, opino que en medio de nuestra alegría por las renovaciones acaecidas tras nuestro contacto con las ciencias sociales, hemos de reconocer que la ciencia del Folklore no ha logrado reconstruirse definitivamente desde el hundimiento de la escuela histórico-geográfica que llegó a sus mayores triunfos entre los folkloristas finlandeses en los primeros decenios de este siglo. En los años 30 y 40 nos hemos mantenido a flote gracias a la psicología y la nueva ciencia del estudio de los géneros literarios. En los años 40 y 50, llega la ola del funcionalismo y del estructuralismo. Todo esto ha significado grandes conquistas para la ciencia folklórica [...] a medida que los antropólogos se dedican a trabajos de campo en Europa, los folkloristas se verán obligados a definir mejor su ciencia y a precisar más cuáles son sus métodos, de modo que quede claro que no se trata de un modo anticuado de llevar adelante la antropología social.

Henningsen no produjo ni un solo artículo con toda aquella ingente cantidad de material visual y auditivo, amén de las mil páginas de anotaciones acumuladas a lo largo de su trabajo de campo. De todo aquello entregó una copia a la universidad, que le había financiado la estancia en España, y al Instituto de Folklore de Dinamarca el material musical. Desde el punto de vista etnográfico únicamente produjo en ese informe una reflexión personal muy esquemática en tres páginas sobre la parroquia de Ardemil. Sus disquisiciones metodológicas iban encaminadas a justificar un cambio estratégico en la investigación: «creo haber explicado mis dudas sobre la efectividad de un estudio comparativo de la brujería en tres sociedades europeas». Abandonaba, pues, el estudio comparativo: ¿hacia dónde iba a dirigir su investigación? ¿Iba a abandonar acaso también el tema de la brujería?

Tenemos un dato seguro de que no iba a ser así. Figura al inicio mismo del informe donde da cuenta del hallazgo «de unos papeles con los informes del inquisidor Alonso de Salazar Frías sobre su largo viaje por las Provincias Vascongadas en 1612 con el Edicto de Gracia para los brujos de aquella región». Afirma que son unos documentos cuya importancia le sugiere "dar a mi investigación una perspectiva histórica». Sin embargo, de manera muy críptica la frase que le había precedido decía «Durante mi trabajo de campo en Galicia comencé a dudar de la eficacia de un estudio comparativo». Si bien ya he ilustrado un aspecto epistemológico para suspender su reflexión folklor-etnográfica, veo conveniente despejar también el enigma de por qué un fieldworker necesitó acudir a los archivos históricos. Pues bien, Henningsen había acudido a ellos debido a que suponía que en el pasado encontraría luz sobre cómo fueron significadas por los tribunales aquellas «mismas creencias que pervivían» todavía hoy. Esta motivación indica que aún 
persistía en él el paradigma folklorista de la autonomía y similitud entre creencias de siglos pasados y las de nuestros días. La lectura de libros importantes como los de Caro Baroja, que le conducían directamente a los de Henry Charles Lea, le habían abierto cierto horizonte archivístico de expectativa metodológica. De hecho, en los archivos dio con dos centenares de procesos de brujería concernientes a Galicia que provenían del Tribunal de la Inquisición de Santiago de Compostela.

En el inventario final de ese informe de 1969 se menciona entre otras entregas a su universidad la de tres mil xerocopias «de manuscritos relacionados con la Inquisición española del AHN [...] (que contienen) todo el material de información sobre procesos de brujería y hechicería de los Tribunales de la Inquisición de Galicia y Navarra». Y avisaba que iba a «editar los documentos más importantes».

Así fue como "o ome que vive dos contos», pese a sonsacárselos a muchos vecinos, no relató él ninguno. Pero al año siguiente sí publicó un artículo de corte histórico en relación con la brujería comenzando a reinventarse a sí mismo como historiador. En la fotografía de cuadragenario en ciernes, tomada en 2015 por el periodista gallego durante la inauguración de la exposición del Museo do Povo Galego, Henningsen era presentado como "antropólogo histórico y experto en folklore». Cincuenta años de trabajo le habían conferido ya el marchamo de historiador.

Antes de asomarnos a ese otro período de nuestro hombre, haré relevante en él otra circunstancia que subraya también aquel señalado rasgo del asombro. Habiéndose trasladado al santuario de la Virgen do Corpiño, en Lalín, con ocasión de la Sanjuanada, por ser momento privilegiado de peregrinación y de sanación de ameigados, Henningsen aceptó el descarnado envite de los hechos dejándose impregnar por la realidad. En lugar de rechazarla, sea alejándose del infernal espectáculo de los sobrecogedores chillidos y gritos de los enfermos o bien quedándose, socarrón, para imponer a los hechos sus propias ideas, quiso entenderlo todo: «tuve que sobreponerme a una serie de ideas preconcebidas y prejuicios, antes de llegar a comprender lo que realmente ocurría en aquel lugar». Lo que allá ocurría eran fe cristiana y una terapia de exteriorización con «descarga de los problemas personales» practicados por el sacerdote en función de escucha y confesor, raras veces de exorcista. Notoria porosidad, pues, ante los hechos como carácter del investigador, la cual le había llevado poco antes a la elaboración de un cuestionario de cincuenta preguntas como respuesta al sorpresivo método etnográfico de Lisón Tolosana.

Quien años más tarde se convertiría en «muller dos contos galegos» fue su esposa Marisa tras investigar en la narrativa oral y configurar ochenta y cinco cuentos gallegos dentro de un anclaje matrilocal. La mitad de ellos fueron recogidos directamente por ella misma y algunos pocos ya lo habían sido por su esposo. Todo ello fue publicado en un libro sobre el mundo de la campesina gallega ${ }^{15}$.

15 Rey-Henningsen (1994). Los cuentos, también en inglés, se hallan en el segundo volumen publicado dos años más tarde. 


\section{EL HOMBRE QUE HIZO HABLAR A ARCHIVOS ARCANOS (1969-1973)}

Con las indicaciones de la obra de Lea además de las de Caro Baroja, Henningsen se trasladó a Simancas a la husma de los documentos, «but there I was told that all the Spanish Inquisition archives were now in the Archivo Histórico Nacional in Madrid. Pleased and expectant I retourned to the national history archives in Madrid». Pero su gozo en un pozo, todo aquel material había sido recatalogado y nadie le daba razón de nada en los archivos madrileños. Una vez más pudo su tenacidad: «Only after a systematic study of the disposition of the Inquisition archives in Simancas and in Madrid» dio con el botín ${ }^{16}$. Al fin y al cabo era del oficio. La descripción, casi forense, que el propio Henningsen ofrece de su monumental hallazgo del legajo 1679 proveniente del Archivo de la Inquisición en Simancas, es esta:

con sus casi 4000 unidades estaba dividido en tres diferentes series, cada una con su propia numeración correlativa: «Libros encuadernados», «Legajos en cuartilla»y «Legajos en folio».

En cada una de las tres series había una sección titulada «Inquisición de Logroño»; mas en las dos primeras no encontré correspondencia con la referencia de Lea. En cambio sí encontré correspondencia en la tercera serie que contenía dos legajos en una subsección titulada «Procesos de fe», tal y como decía la nota del autor americano. Uno de los legajos correspondía al siglo XVIII, y por lo tanto se podía descartar. El otro, en cambio, procedía del siglo XVII, por lo que me resultó relevante. Sin embargo, sobre el contenido no ponía más que: «Este tiene algunas piezas foliadas, pero en lo general carece de numeración». A juzgar semejante descripción, el contenido no podía ser de mucha importancia. De momento dejé de hacer el pedido de dicho legajo; pero después de haber examinado otras referencias de Lea, comparándolas con el «Índice de Simancas», llegué a la conclusión de que, a pesar de tan anodino título, tenía que ser el mismo al que hacía referencia Lea.

Así pues, un día de diciembre de 1967 me hallé en la sala de lectores con un cajón de archivo de varios kilos de peso sobre la mesa. Además de contener los informes de Salazar, albergaba también un tesoro de material hasta entonces desconocido... un tomo de su libro de visita que, de estar completo, comprendería 6200 folios con los interrogatorios de casi 2000 brujas confesas. Y para colmo, el tomo más importante de todos, el que contenía los ochenta «revocantes», es decir personas a las que, como algo excepcional, se les había permitido desdecirse de sus confesiones. En resumen: un material único.

Imagínese que en los archivos daneses encuentra usted varios kilos de legajos del siglo XVII que hablan de tribunales, interrogatorios y sentencias, de los cuales no existía más que liviana referencia de segunda mano. Legajos ignotos para el historiador pero perentorios para elaborar la historia moderna del país. Imagínese que usted mismo se

16 Henningsen (2004, IX). Se trata de aquella documentación, tanto tiempo demorada de los testigos directos de la persecución (Salazar, el obispo de Pamplona y el jesuita Solarte entre otros), presentada en español junto a una impecable traducción inglesa realizada por la señora Julia McDonald, esposa de C. Lisón Tolosana, con la asistencia de Marisa Rey Henningsen. El libro tiene un largo e importante prólogo en inglés. 
propone descifrarlos. Es decir, quemarse las pestañas leyéndolos las veces que haga falta en una escritura a mano de un danés antiguo y con una caligrafía siempre procesional y a menudo floral. Y a la vez que usted se va enterando de algo, va estableciendo cajones y cajones alargados de fichas en orden alfabético con su contenido preciso por temas, por años, por personajes, etc., escribiendo también en centenares de cuadernos los posibles laberintos de acción, geografía, tiempo y otro tipo de circunstancias que le ocurran a su curiosidad. Además, usted tiene cierta prisa para culminar ese objetivo pues le han contratado solo por tres años, japáñeselas usted!

Henningsen se las apañó para poder en ese año, a caballo entre 1968 y 1969, presentar un croquis cartográfico bastante exacto del contenido de aquellos documentos. Lo publicó en inglés en una revista finlandesa de estudios comparados de religión con el título «Los documentos de Alonso de Salazar y Frías. Una polémica sobre brujas 1610$1614 »{ }^{17}$. Envió una separata del artículo a Caro Baroja pues el año precedente ya le había informado con pelos y señales de su hallazgo en el Archivo Histórico Nacional. Se había apresurado también Don Julio a acudir a los archivos donde, efectivamente, encontró los documentos poniéndose con celeridad a trabajarlos. En muy poco tiempo elaboró un largo y espléndido artículo, seguramente lo mejor de cuanto escribió sobre la brujería ${ }^{18}$. Durante ese corto período, Henningsen sacó también tiempo para colaborar con dos estudios (Hechicería y artes secretas; Procesos de brujería) en sendos tomos de un libro sobre la vida cotidiana en la Dinamarca de 1629-1720 (Henningsen, 1969, pp. 161-196, 727-731). También fue contactado en Copenhague por el antropólogo W. Douglass, profesor en la Universidad de Nevada, a quien antes ya había conocido, precisamente en Itzea, la casa de los Baroja en Bera de Bidasoa. El antropólogo americano, vivamente interesado por el hallazgo de los papeles de Salazar se proponía él mismo para editarlos en su universidad al amparo de los Basque Studies. No ocurrió exactamente así pues esa historia tuvo algunos avatares adversos.

Henningsen vino a España con sus tres hijos a finales de ese 1969 e, instalándose en Madrid, culminó en tres años de intensa labor su investigación histórica entregándosela a la universidad en inglés a modo de tesis doctoral. En Dinamarca empero, una investigación no puede ser defendida como tesis doctoral a menos de ser antes publicada. Las prensas universitarias de Nevada University precisaron de un largo proceso de copy editing y el propio Henningsen se atardó mucho en sucesivas consultas en los Archivos de Navarra y otros. De manera que solamente en 1980 vio la luz el primer tomo de la

17 Henningsen (1969, pp. 85-106). Este artículo fue reimpreso en 1992 por B. P. Lewack [ed.], Articles on Witchraft, Magic and Demonology, New York, t. 5.

18 Caro Baroja (1969, pp. 741-802). Al final del artículo escribió así: «Al corregir pruebas segundas de este artículo me envía el Sr. Gustav Henningsen un importante estudio acerca de "The papers of Alonso de Salazar Frías. A spanish Witchcraft polemic 1610-14”, publicado en Temenos V (1969, pp. 85-106). Parece por él que incluso va a escribir un libro entero acerca de Salazar».

El artículo fue introducido al año siguiente (Caro Baroja, 1970) y en él Caro Baroja establece una nota ( $5^{\text {bis }}$ ) para ofrecer el Índice de los papeles del legajo 1679, en cuyo final notifica que Gustav Henningsen «va a publicar gran parte de esa documentación». Cuando también con esta misma noticia se publica la 3. a edición que obra en mi poder (1974), ya hacía un año que Henningsen había depositado en su universidad toda esa documentación sistemáticamente analizada y comentada en inglés, por si era aceptada como tesis doctoral. 
tesis doctoral, que se conoce como El abogado de las brujas. Su complemento iba a ser otro tomo con los más importantes documentos de Salazar y algunos otros, pero quedó a la espera de ser editado. Sin embargo la edición española, con traducción de Marisa Rey-Henningsen, no apareció hasta $1983^{19}$. El libro tuvo un enorme eco en la prensa especializada y lo analizaron hombres de gran prestigio académico como Macfarlane, Kamen, Coronas Tejada, Ankarloo, García Cárcel, Monter y un largo centenar de especialistas y críticos literarios. Impactó sobremanera la abrumadora cantidad y calidad de la documentación utilizada para reconstruir con precisión los hechos de persecución de brujos que ocurrieron entre 1609 y 1614 en el noroeste de la Navarra española y territorios aledaños, guipuzcoanos y alaveses especialmente. Causó también cierto impacto el que con ese mismo rigor científico un historiador luterano reivindicase de manera probante la persona de un inquisidor español como figura señera de búsqueda de la verdad en la Europa moderna. Precisamente a él se refería el título de ese libro que hacía luz sobre tan oscuros como mitificados hechos brujeriles de Zugarramurdi, pues «abogado defensor» de las víctimas fue él, el inquisidor Alonso Salazar Frías. Basándose en ello y con mucha determinación se atrevió Henningsen a anunciar de manera rotunda al inicio del libro, en el Prefacio mismo, que «si las víctimas del resto de Europa pudiesen levantarse de las cenizas de las hogueras, declararían como las de España: Fuimos inocentes» (p. 39). O sea, un anuncio de lo que el inquisidor Salazar logrará al final del libro: hacerle declarar a la Suprema de la Inquisición, en agosto de 1614, que todos aquellos acusados de lengua vascuence, tanto asesinados como reos y absueltos, eran inocentes. Esta inocencia la exigieron al poco por escrito las veintiséis víctimas que en Zugarramurdi sobrevivieron a acusaciones, prisión y pena capital. Ante la noticia de que estaba próximo a morir el abad que inició las acusaciones -lo que le había reportado un cargo inquisitorial-, todas ellas se personaron en el monasterio de Urdax para que, antes de morir, Araníbar restableciese la verdad de que ninguna de ellas había hecho maleficio ni había sido bruja jamás y de que sus declaraciones se debieron a la violencia ejercida sobre ellas. Cosa que certificó el abad.

\section{EL HOMBRE QUE ACLAMÓ A UN INQUISIDOR Y SU JUSTICIA}

The Witches' Advocate está dedicado «A la memoria de D. Alonso de Salazar Frías, inquisidor y humanista español». Antes de su publicación ya se había presentado Henningsen a sí mismo como admirador del inquisidor Salazar en un artículo de homenaje a Caro Baroja (Henningsen, 1978, pp. 581-586). También había asegurado en otro artículo-primicia que, si sabemos a ciencia cierta que el asunto de Zugarramurdi no tenía nada que ver con sectas brujeriles ni con alucinaciones por consumo de drogas, era «gracias a las pesquisas realizadas... especialmente por Salazar» (Henningsen, 1979, p. 194). Y coincidiendo con la publicación inglesa del libro, aprovechó Henningsen la invitación de una revista londinense especializada en historia para publicar aquel extracto de su libro que más ilustrativo debía de parecerle ante los aficionados a la

19 Henningsen (1980b). Versión española, Henningsen (1983) y existen también versiones danesa (1981), sueca (1987), húngara (1988) e italiana (1990). 
historia: un enfoque sobre las vicisitudes del largo y controvertido procedimiento judicial tenido en Logroño entre 1609 y 1613 . Son estos el comienzo y el final del artículo (Henningsen, 1980, 1982):

El verano de 1613 los inquisidores de Logroño se vieron muy atareados... Intentaban resolver el mayor proceso de brujería que conoce la historia, tanto en el aspecto cuantitativo (comprendía 7000 causas) como el cualitativo; pues como uno de los inquisidores lo expresó satisfecho, ese fenómeno nunca había sido investigado tan a fondo. La verdad es que tampoco lo fue desde entonces...

[...] Tan tarde como en 1791 procedió el tribunal de Barcelona contra una mujer acusada de pacto con el demonio. Por lo visto aún quedaban inquisidores del género especulativo, que pensaban en dirección contraria a la de Salazar Frías, el abogado de las brujas ${ }^{20}$

Ese inquisidor, ufano en 1613 de haber llevado a cabo una investigación a fondo, era Salazar; y el otro que, casi dos siglos más tarde, todavía «especulaba» con pactos demoníacos iba en la dirección de los perseguidores europeos, contraria a la de Salazar. Puede que este brevísimo artículo de Henningsen sea el extracto más a su gusto de todo su libro pues los gravísimos hechos (de persecución, acusaciones forzadas, violencia vecinal, disensiones entre inquisidores, tenebrosas mazmorras, un camelo de tribunal, auto de fe, hogueras, ensoñaciones, pánico, colapso social, etc.) ocurridos durante varios años dentro de la jurisdicción inquisitorial logroñesa quedan configurados como segmentos de un procedimiento judicial con sensata solución final. Es como si ese final inquisitorial del «no hubo brujería» y "hágase en adelante silencio» diese el sentido a todos aquellos hechos.

Como lector crítico de ese portentoso libro, de tener yo que efectuar un brevísimo extracto para Historia 16, habría subrayado el terror que provocó la persecución dirigida por las élites monopolizadoras del poder de Estado y la consiguiente espantada hacia el colapso cultural de aquel vecindario de alrededor de ocho mil almas sin apenas poder entender lo que les había pasado y sin saber a qué atenerse en adelante a resultas del «perdonen ustedes, pero no se hable nunca más» final que emitió el perseguidor. Otro lector del libro de Henningsen podría objetar que mi configuración de los hechos mira más a la víctima que al insólito modo en que los controles del poder religioso pudieron rectificar el tiro de su injusticia en tanto que los del poder civil no lo rectificaron en España y tardaron más de cien años en hacerlo en el resto de Europa. Un hecho de rectificación inaudito que se debió al inquisidor Salazar y que le sirve al propio Henningsen para responder a menudo al entrevistador: «Fue él quien cambió el rumbo del tribunal evitando así un holocausto». Yo podría argumentar de nuevo desde el libro pero también podría contra-argumentárseme con mucho tino desde él: esa es la riqueza de El abogado de las brujas, plausible de lecturas desde diversos ángulos, con muy variada nutrición y matices tan diagonales e insospechadas sugerencias que lo vuelven

20 Henningsen (1980a). Este artículo, traducido por Marisa Rey-Henningsen, se publicó como «El mayor proceso de la historia: Navarra, 1609-1614» en Historia 16, 1982. 
un nacedero de hipótesis abiertas a la espera de nuevas investigaciones sociológicas, históricas, políticas y hasta semánticas. Y así es el libro, pues resulta ser un conjunto no de fotografías sino de carretes en blanco y negro que uno puede ir revelando en su laboratorio según los prismas desde los que intente mirar hacia los hechos del pasado.

Sin embargo, el libro sí ofrece un relato temporal y causal de los hechos. O sea, nos entrega una crónica sólida de lo que pasó.

Esta crónica hace luz sobre aquel extraño asunto de caza de brujas que rompía con la tradicional benignidad de la Inquisición y saja por lo sano cualquier teoría pagano-feminista-milenarista a lo M. Murray, Jules Michelet o Marvin Harris. Muestra que fue la persecución la que hizo extenderse la noción misma de brujería satánica: primero, mediante la violencia de tribunales, mazmorras y un terrible auto de fe en Logroño. A ello siguió una irrupción misionera de horripilantes sermones dirigidos al insensato adoctrinamiento de brujería demoníaca junto con obligatorios confinamientos nocturnos de niños y mozos. Como resultado, estos se pusieron a soñar o impulsados a decir que malsoñaban con el contenido de aquel adoctrinamiento y, en consecuencia, a sufrir presión y hasta amenazas y tortura para acusar a gente conocida. De esta manera cada supuesto soñador acusaba de acudir a las juntas nocturnas del diablo a cinco, diez o más personas. Así es como fueron denunciados más de cinco mil nombres por 1721 personas que confesaron ser brujos-brujas, además de las 1672 denuncias de ochenta y una personas que revocaron sus confesiones de brujería.

Esta crónica dilucida también el hecho de que las instituciones están formadas por personas y que estas son las que les dan un definitivo tono y color. Personas insensatas o corruptas confieren siempre a la institución un derrotero y, a menudo, su carácter. Bastaron dos inquisidores malvados, un abad corrupto, unos cuantos taimados comisarios inquisitoriales, otros tantos alcaldes con algún que otro clérigo al servicio de intereses de algunos señoritos (al menos Jaun de Urtubi-Alzate y Jaun de Zabaleta con toda seguridad) para aterrorizar a toda la población al socaire del tinte de hostilidad intervecinal, del que siempre iba ungido el sentido común campesino enraizado en sorgin (potencia de mal o lo que se suele llamar brujería). Pero para enderezar aquel colapso social y cultural se necesitó un inquisidor justo, apoyado por un obispo recto rodeado de clérigos de mucho sentido común. Además de estas luces se requirieron también apoyos en las altas instancias de la Inquisición. Por eso tenía razón Henningsen cuando afirmaba a un entrevistador: «Lo que me fascina del carácter de Salazar es su amor a la verdad sin concesión. La lección que esto nos aporta es la importancia de que las personas dentro del sistema, donde sea -en la política, la justicia o dentro de la policía- han de tener valor para revelar las cosas ilegales que se cometen a su alrededor o se intentan silenciar. Como termino diciendo en mi libro: «El mundo siempre tendrá necesidad de alguien que se atreva a desenmascarar al verdugo: de hombres tan enteros como Salazar» ${ }^{21}$.

21 Euskonews, 553, 2010/11/05-12. Entrevista efectuada por Juan Agirre Sorondo, «Gustav Henningsen. Folklorista e historiador", con motivo del homenaje que el Ayuntamiento de Zugarramurdi y el Gobierno de Navarra le rindieron a Gustav Henningsen por el 400 aniversario del Auto inquisitorial de Logroño, en noviembre de 2010 . 
En efecto, estas son las últimas frases del libro. «Desenmascarar» hace referencia a la falsedad con disfraces de verdad y «verdugo» a quien se sirve de ella para perseguir.

Comienzo y final, de aperitivo y postre, Salazar, un inquisidor fidedigno y veraz como personaje de un libro de microhistoria persecutoria, ¿no es esto acaso extraño viniendo de un hispanista nada crédulo? Se trata del efecto-asombro del que hablé más arriba: el encuentro con Salazar despojó de todo prejuicio nórdico y luterano a Henningsen. El danés, un hombre esponjoso ante lo real, entendió a un inquisidor como nadie de nosotros es capaz de hacerlo. Por eso lo enamoró. A Caro Baroja no le embelesó Salazar tanto, pero fue recio también en repartir mandobles a quienes equiparaban por igual a los tres inquisidores de Logroño. A Moratín, por ejemplo, por poner «de chupa de dómine a los tres y al Santo Oficio» enjuiciando «la persona de don Alonso de Salazar del mismo modo como enjuició las de sus dos colegas». O a Menéndez Pelayo por haber dado "como bueno todo lo que se cuenta en el Auto de Logroño". Por eso, tras un acelerado ojeo de los documentos pudo Caro Baroja comenzar su análisis con Salazar (cuyo método «fue de una minuciosidad que asusta un poco») y al ir terminándolo, escribir que «el santo Oficio fue un tribunal mucho más enigmático de lo que se dice» ${ }^{22}$.

¿Qué es, pues, lo que Salazar hizo de extraordinario? Cumplir con las normas tradicionales de la Inquisición y tratar de hacerlas cumplir. En particular las resoluciones de febrero y diciembre de 1526 tomadas por el Consejo de la Inquisición, en Toledo, y dirigidas ambas a los inquisidores de Navarra: $1 .^{\circ}$, para criticar el procedimiento del poder civil en la recentísima represión a los aldeanos de la comarca del Roncal y valles aledaños; $2 .^{\circ}$, para pedir verificación minuciosa de todos los males supuestamente cometidos (asesinatos de niños, destrucción de mieses y producción de tormentas) así como de todas las circunstancias de tiempo, modo y lugar en que decían producirse los vuelos nocturnos hacia las juntas brujeriles; y $3 .^{\circ}$, para evitar que se sonsacasen declaraciones de brujería mediante la violencia utilizándose únicamente formas de trato personal amistoso con los supuestos brujos ${ }^{23}$. Ambas resoluciones de 1526 se habían vuelto norma inquisitorial evitando dar fe a las aseveraciones diabólico-maníacas del Malleus Malleficarum, con lo cual habían impedido durante ochenta y cuatro años que tribunal inquisitorial alguno condenase a nadie por brujería a la hoguera. Eso hasta los hechos de Logroño precisamente. En la denuncia de Salazar a toda la causa llevada en Logroño se informaba que no solo no se cumplían estas antiguas normas de procedimiento, sino que sus dos colegas inquisidores las escondieron a posta al resto del personal del tribunal. La verdad es que esos colegas exudaban la melancolía diabólica del Malleus. En su Informe Cuarto al Inquisidor General (1613) explicaba pormenorizadamente las

22 Caro Baroja (1974, pp. 279-280). Estas citaciones las tomo del cap. I y de las consideraciones finales, pero el cap. XII está dedicado por entero a Salazar y a los escritos sumamente razonados que iba enviando al Consejo de la Suprema así como a las muchas dificultades de convivencia con sus dos colegas de Logroño.

23 «[...] porque ha parecido que, para más verificación de la verdad de los delitos, así de los principales como de los que de ellos dependen, se debian hacer más diligencias de las que parecen hechas por los dichos procesos" (Archivo Histórico Nacional, Inquisición, lib. 319, ff. 270r-271v). Y «[...] sea amonestada con todo amor o palabras de caridad [...]. Han de advertir mucho los inquisidores si las personas que están presas o encarceladas, si fueron primeramente atormentadas por la justicia seglar y la manera de los tormentos [...]» (AHN, Inquisición, lib. 319, ff. 348r-349r). Citadas del Anexo 3 de su ponencia (Henningsen, 1998). 
irregularidades cometidas por el tribunal, culpándose él mismo de algunas. Henningsen consagra el espléndido cap. XI del libro a los tira y afloja habidos entre los tres inquisidores de Logroño, una genuina «batalla» según la llama.

La mejor autocrítica de Salazar fue sin duda el periplo de nueve meses investigando por las aldeas de la persecución, un operativo que restableció la cordura racional de las resoluciones de 1526. Investigó uno a uno a los acusados exigiéndoles pruebas y detalles de vuelos y juntas, así como los porqués de haber acusado a otros. En contra de la opinión de sus colegas, facilitó la retractación del acusado -conforme ordenaba la vieja ordenanza- y levantó acta de cada investigado. Los más de cinco mil folios que llenó en ese operativo avalaron la contundencia final de la Suprema de la Inquisición en 1614. Sus dos colegas prosiguieron empero llamándole «defensor de brujos».

Previamente a esta última y definitiva resolución de la Suprema que dio fin a la persecución, Salazar había escrito un alegato, el séptimo, cuyo título reza «Lo que convenía proveer en el remedio de este negocio de la secta de brujos». Henningsen lo ofrece en entero por su importancia. De entrada reclamaba condolerse con las víctimas por la violencia ejercida así como también castigar, en primer lugar, a las instituciones civiles y a las parentelas de los acusados. Luego se refería asimismo a la violencia y errores de los propios inquisidores y comisarios: pedía también para ellos castigo. $Y$ así fue reseñando otras dieciocho propuestas a tener en cuenta. En una de estas reclamaba la imposición pública de un completo silencio sobre asuntos de brujería. Salvo cinco propuestas, la Suprema aceptó todas. Una de las no aceptadas fue extender también el castigo a los miembros de la inquisición. Y así fue como se promulgó un Edicto de Silencio que incluso prohibía a las víctimas comentar sus propios avatares inquisitoriales, vejaciones y daños sufridos. Henry Charles Lea había calificado esta decisión inquisitorial de «viraje decisivo en la historia de la brujería» y Henningsen en el epílogo del libro le atribuyó el que «España se adelantase cien años al resto de Europa». ¿Tiene acaso también razón cuando sitúa "a Salazar en la Historia de la Ciencia como un empírico precoz» ?24

\section{EL HOMBRE QUE INTERPRETÓ DE NUEVO MODO LOS HECHOS DE PERSECUCIÓN BRUJERIL}

Esta narrativa del epílogo que he comenzado a citar es la que produce el corte entre crónica de los hechos y discurso distintivamente histórico. En esa narrativa del final de libro es donde precisamente se aborda el sentido de aquellos hechos. O sea, su interpretación.

Para mi propósito aquí, me bastará con enunciar tres conceptos que impregna Henningsen a su crónica de los hechos haciendo que la verdad fáctica se vuelva también figurativa; es decir, represente hechos, los configure. Primero, está su visión general de

24 En una ponencia de 1998 abundó en esta idea, asegurando que la pesquisitiva expedición de Salazar por los lugares de la brujería tuvo el «carácter de una moderna expedición científica» (Henningsen, 1998, p. 589). 
que la brujería es una creencia. Segundo, está su visión de que la explosividad de todo aquel asunto en las tierras del vascuence consistió en una epidemia de brujomanía. Y, tercero, está su visión de que el silencio era el remedio a la brujomanía.

1. Su primer supuesto es antropológico y emplaza la brujería en tanto que sistema popular de ideas en las que se cree. Las del aldeano llano serían un «credo brujeril» muy útil para resolver problemas cotidianos tales como explicar males inexplicables a base de perseguir a personas concretas supuestamente malas. Haciéndolo, la gente se alecciona y no obra el mal a fin de no ser uno mismo considerado brujo y evitar ser perseguido. De paso que se persigue a alguien, es como si la gente dejase escapar sus instintos agresivos.

En contrapartida a esa brujería popular estaría la de la élite culta rebosante de teología, donde las creencias en el demonio como adversario de Dios establecerían todo un dispositivo de hacer el mal en la sociedad y de ponerla patas arriba mediante su adorador, el brujo.

2. El segundo supuesto es sociológico y acepta que el credo brujeril-demoníaco de la élite culta se propagó entre el campesinado merced a sermones y predicaciones, y que la mezcla de las creencias campesinas con las creencias cultas trastornó las mentes de la población. Se produjeron experiencias oníricas en masa, especialmente infantiles, haciendo brotar epidemias de brujomanía colectiva. Es decir, «una forma explosiva del impulso de persecución», breve pero muy dura por afectar a una masa considerable de la población. O sea, la brujomanía aportó esencialmente una perturbación psicológica de mucho fuste. Una intervención inquisitorial muy mal llevada originó un mayor desbarajuste social y únicamente la pesquisitorial metodología, tan bien conducida por Salazar, promovió la calma social desactivando la persecución.

3. En consecuencia, aflora el tercer supuesto en Henningsen que es meramente lógico: el silencio final de la Inquisición era lo adecuado. Lo era porque era correcta la propuesta de Salazar: "no hubo brujos ni embrujados en el lugar hasta que se comenzó a tratar y escribir de ellos». Por tanto, si toda brujomanía provenía de discursos y sermones que informaban de una brujería-demoníaca, debería bastar con que jamás se diese información ninguna respecto a hechos de brujería. Consiguientemente, el silencio total como terapia.

La presunción antropológica de Henningsen la veo cuestionable pues es una explicación funcionalista contradictoriamente ingenua. Como el investigador no cree en brujas ni en que ellas maten a niños y hagan tempestades y plagas en cosechas, da en suponer que el campesino sí cree de manera infantil en todo ello. Y además da en suponer que, esa creencia falsa ( «la brujería es por definición un crimen imposible» p. 345 ) le es socialmente útil al campesino tradicional pues persigue a gente mala y, así, él se desfoga. Sin embargo, no es difícil darse cuenta que, si la gente campesina creyese en gente mala a la que castigar y, de hecho, la castigaba, esa no sería una «función de chivo expiatorio» sino una función vindicativa o de justicia directa, análoga a la que usamos nosotros mediante tribunales de justicia. El chivo expiatorio lo es porque siempre es inocente, y no es tan insensato el campesino de castigar a inocentes. 
$\mathrm{Al}$ parecer, se trata de una presunción que rezuma el sesgo general de su primera educación universitaria como folklorista coleccionador de creencias en tanto que formas de vida social. En otro lugar he dado mi opinión sobre la naturaleza de la brujería ${ }^{25}$ y solamente añadiré que los campesinos del vascuence vivieron probablemente la brujería como un supuesto semántico del sentido común, algo análogo a como hoy vivimos nosotros en otros supuestos que tienen que ver con la causalidad científica, incluida la telemática. En cambio para los teólogos imbuidos del Malleus maleficarum la brujería sí era una creencia, precisamente en el diablo y su malignidad proactiva con quienes pactaban con él. Además, ellos -los perseguidores- tenían otra creencia más: la de que los campesinos creían en eso mismo pero lo disimulaban o escondían.

La segunda presunción sociológica de Henningsen parece funcionar porque carece de la Basque connection. Primero y antes que nada, se sabe que fue la lucha por el poder entre dos fracciones sociales del Pays des Basques (Labourd), una de las cuales logró perseguir a la otra desde los supuestos brujeril-demoníacos de la élite culta francesa apoyándose en el rey y en dos jueces sin escrúpulos pero con calabozos, torturas, cadalsos y hogueras ${ }^{26}$. Justamente valle abajo de Zugarramurdi. Siguió un espanto general en las aldeas aterrorizadas, cuya población huyó en masa despavorida hacia Navarra y Gipuzkoa dando información de cuanto ocurría y qué versión era la adecuada para salir con vida del tribunal. Zugarramurdi, situada tras los montes en pleno valle labortano de basques, fue la primera víctima navarra de la nueva versión brujesco-demoníaca inquisitorial, pero la información provenía de muy cerquita, del castillo de Amu precisamente, sede del perseguidor francés y de su tribunal. Enseguida, tras el espanto popular por las hogueras de noviembre de 1610 en Logroño, advinieron los franciscanos y algunos comisarios y sacerdotes sin escrúpulo atronando sobre la creencia brujesco-demoníaca tanto desde púlpitos como mediante aterradoras noches de secuestro de niños y jóvenes. La «brujomanía» de la población fue resultado de los obligatorios informativos puestos en marcha por la persecución. Era la persecución quien informaba, no eran «creencias» cultas las que venían de no se sabe qué onda informática. La población tenía perentoria urgencia en conocer «lo nuevo» pues le iba la vida en ello. Además, tampoco se entiende por qué la creencia popular brujesca produce como válvula de escape castigos individuales en tanto que su mezcla con la creencia de la élite culta produzca hecatombes sociales: un 25\%-30\% de acusados en cada aldea.

La presunción tercera de Henningsen obra con lógica desde el supuesto de que todo el confrontamiento brujeril fuese debido a ideas propias mezcladas con ideas ajenas, y de que la persecución se estableció a fin de castigar la práctica con nocturnidad de

25 Azurmendi (2010, también 1995, pp. 15-38).

26 Estuvo en manos del propio Henningsen haber transitado por esta pista tan esencial para conjeturar una sobreactuación de María de Ximeldegui al volver a su antigua aldea de Zugarramurdi con el fin de acusar de inauditos hechos brujesco-demoníacos a su amiga María de Xureteguia y familiares. La pista le hubiese también abierto el camino para comprender cómo son intereses espurios los que inician una acusación de brujería con la finalidad de amenazar y perseguir. Se trata de la pista ofrecida por el bibliotecario francés Francisque Habasque en 1912, Episodes d'un procés en sorcellerie dans le Labourd au XVII'è siècle, 1605-1607, la cual Henningsen menta en bibliografía sin tenerla en cuenta. 
ciertas ideas odiosas. Así es como el tribunal procesal-penal de inquisidores de Logroño pueda aparecer como englobando la casi totalidad del sentido de los hechos ocurridos: hechos de brujería cuyo relato hasta podría establecerse como «el mayor proceso de la historia», enseguida reconducido por la Suprema de la Inquisición. Esta aparecería dando el sentido último a la totalidad dictando la verdad: «no he hallado certidumbre ni aún indicios de qué colegir algún acto de brujería que real y corporalmente haya pasado». De ella emanaba el Edicto final: Basta ya de habladurías, cállense todos sobre asuntos de brujería.

Tengo para mí que fue a partir de que aquel silencio terapeútico le pareciese aceptable, como Henningsen concibió el concepto de brujomanía en tanto que condensado de adoctrinamiento + sueños esterotipados + confesiones forzadas. Pero la brujomanía era todo eso cuando te están persiguiendo a muerte. Brujomanía era una sarta de tremebundas procacidades inventadas por ideólogos de la sopa boba, que confundían el mundo de los hechos y el de sus ideas, pero cuyo uso era perseguir. Es de creer más bien que la gente, aterrorizada por comisarios acompañados de hombres armados, no tuviera «manía de brujas» sino lo que tenía era pura necesidad de conocer qué querían escuchar aquellos aterradores energúmenos ${ }^{27}$. Quien sí poseía delirio maniático de brujas era toda esa gente inquisitorial con facultad de matar; el pueblo llano andaba espantado, salido de sí en una justa de vecino contra vecino por el ¡sálvese quien pueda! En una conferencia en danés que data de 1996, Henningsen atribuye a Salazar la detección sociológica de brujomanía:

Aquí me limitaré a mostrar el modo en que Salazar adivinó la brujomanía y su dinámica: «Tengo por cierto -dice nuestro abogado de las brujas- [...] que cualquier modo de ventilar en público de estas cosas, con el estado achacoso que tienen, es nocivo y les podría ser de tanto y de mayor daño como el que ya padecen. El cual silencio y disimulación conveniente también saco de las experiencias que he visto, de que no hubo brujos ni embrujados en el lugar hasta que se comenzó a tratar y escribir de ellos ${ }^{28}$.

Henningsen y Salazar dan en suponer un estado social de paroxismo brujomaníaco pero ninguno de ambos se apercibe de que era la persecución lo que aportaba la anomalía de «comenzar a tratar y escribir» sobre el maleficio demoníaco-brujeril. Que la dinámica la marcase siempre la persecución lo demuestra el que Salazar no persiguiera a nadie en su visita, pese a que trataba con los acusados de brujería. Él pudo interpretarlos de otra manera hablando de ello precisamente.

Considero que la sobredeterminación de las creencias y el consiguiente arrinconamiento de intenciones y propósitos en las acciones de los humanos (así como de sus

27 Acaso venga bien recordar la opinión del obispo de Pamplona, Venegas, tras el largo viaje de visita por toda la zona perseguida: "con haber muchas personas ancianas (encausadas), ninguna sabía qué cosa era ser brujo ni cosa oliese a mala arte, ¡ni qué cosa era “aquelarre!” (abril 1611)», en (Henningsen, 2004, p. 207).

28 Henningsen (1996a). Lo cito del manuscrito traducido por M. Rey-Henningsen «Brujería y brujomanía, antes y ahora", p. 7. 
resultados), ha impedido investigar posibles intereses económicos y políticos en las persecuciones de la raya navarra del Pirineo, tanto en 1525 como en estas de inicios del XVII. En una de las hipótesis abiertas a la investigación, que enuncia el Prólogo, se afirma que «en conexión con persecuciones de esas dimensiones actúan especuladores que aprovechan el revuelo general provocado por la caza de brujos para fines económicos y políticos» y cita al Señor de Urtubie y al párroco de Bera. Pero el libro no percibe que en el acto mismo de persecución pudiesen ir implícitos, si no muy explícitos como en el caso del Labourd, objetivos político-económicos ${ }^{29}$. Caro Baroja, más pegado al conocimiento de la tierra, no dudó en calificar todo aquel asunto como una lección de "cómo se forman situaciones de terror colectivo" en los que se rastrea «la existencia de una situación tensa en la que los señores rurales antiguos, con potestades judiciales, etc., eran los más interesados en mantener sobre las villas y pueblos con pretensiones nuevas la amenaza de la persecución por causa de brujería». Por eso insistió en que debería haberse criticado entonces «el secreto con que obraba» la Inquisición ${ }^{30}$.

Tras elaborar un pormenorizado y utilísimo mapa histórico de la relación entre brujería e Iglesia para mejor situar el rol de la Inquisición española, la citada ponencia de Henningsen ante la comisión teológico-histórica del Vaticano con motivo del jubileo del año 2000 felicitaba, a la vez que daba un tirón de orejas, a Juan Pablo II aprovechando la Tertio milenio adveniente. En ella el papa había pedido perdón animando «a purificarse en el arrepentimiento de errores». Henningsen evocó las quemas de brujas considerándolas a estas inocentes y, acto seguido, criticó a la Iglesia por haber dejado en el secreto las prudentes instrucciones de la Inquisición. De haber sido publicadas, decía, «quizás hubiesen salvado vidas humanas. Mas la Inquisición optó por guardarse su conocimiento para uso interno". ¿Podríamos considerarlo otro indicio de cambio en su apreciación positiva del silencio inquisitorial de 1614?

En esta postrera conferencia de Henningsen se aprecia bien su afán por asimilar los avances conceptuales de los estudiosos a fin de ir depurando su propia teoría. Así el concepto de pánico moral como resultado de reacciones de un grupo de personas por ser consideradas desviacionistas o amenazadoras. Concepto del que se sirvió para hacer un análisis comparativo entre supuestos abusos de niños en nuestros días y los sueños demoníacos que padecieron los niños durante la persecución navarra (Henningsen, 1996b). Data también de este período su trabajo de revisión de los legajos históricos, por si resultase verídica la hipótesis del aquelarre como fabricación-exprés de los inquisidores de Logroño. Sorprendido por la relevancia de la hipótesis, Henningsen puso toda la carne en el asador hasta descubrir la fecha exacta del capcioso informe de los dos inquisidores a la Suprema (Henningsen, 2001). Dado que siempre pensó que su interpretación podía y debía ganar en veracidad, abordó temas como el de las hadas

29 Sin embargo en su ya citada ponencia de 1998 ante el Vaticano Henningsen deja suelta esta indiciaria frase "Cuando la quema de brujas volvió a introducirse en el norte de España, en 1610, bajo la influencia de Francia» (Henningsen, 1998, p. 589) ¿Qué género de influencia de Francia? ¿Se indician acaso intereses espurios en el perseguidor de Zugarramurdi?

30 Caro Baroja (1969, 1974), las citas las tomo de las consideraciones finales. 
en tanto agentes benéficos metaforizando de «sabbath blanco» sus juntas. Asimismo el tema de la brujería desde la opinión pública (Henningsen, 1990, 1991-1992, pp. 293304, 1995, pp. 5-14).

\section{EL HOMBRE QUE DESCORRIÓ LA CORTINA QUE CUBRÍA A LA INQUISICIÓN}

Ya cuatro años antes de que fuese publicada su tesis doctoral sobre la brujería en Navarra, se presentó Henningsen ante los investigadores de la universidad con una reclamación fuera de uso: era posible y necesario superar el legado histórico de Lea y Schäfer sobre la Inquisición.

No se ha(n) investigado todavía los orígenes y evolución de los tribunales ni trazado un mapa donde se nos muestren los límites de los distritos inquisitoriales; no se nos ha proporcionado una monografía sobre un tribunal y su organización, con la distribución de los comisarios y familiares por el distrito correspondiente.

Proseguía enumerando otros aspectos más que urgían ser investigados y, por consiguiente, establecía una enmienda general al supuesto entonces dominante, defendido también por Caro Baroja, de que nuestro conocimiento de la Inquisición era casi exhaustivo. También daba a conocer que dos de sus discípulos, J. Contreras y J-P. Dedieu, ya habían comenzado a investigar algunos de esos aspectos. Auguraba además que en años venideros «los archivos del Santo Oficio tendrían que prepararse a una invasión de investigadores» (Henningsen, 1977, p. 568). Henningsen ha sido un adelantado, si no profeta, en estas intuiciones pues sus discípulos han producido importantes obras y la historia de la Inquisición se ha constituido en un importante eje de nuestro conocimiento de la sociedad de la época. En un simposio celebrado en Cuenca al año siguiente de ese, llamémosle manifiesto, Henningsen reunió a más de trescientos interesados en el tema de la Inquisición.

Para entonces, siempre influido por su bagaje metodológico folklorista de ir a la pesquisa de las supersticiones, ya trabajaba él junto con un ayudante, J. Contreras, en la recolección de las relaciones de causas del Santo Oficio, un proyecto subvencionado por el Consejo danés de Investigaciones Científicas. En unos años no solo habían coleccionado ambos 44000 causas $^{31}$ sino que las habían repertoriado según diez tipos de delito con un índice cronológico-geográfico, dada la vastedad del Imperio español que cubría desde Sicilia hasta Filipinas pasando por Perú. Sorprendió a los historiadores conocer que el Santo Oficio español, a partir de mitad del siglo XVI, se había convertido en un tribunal para juzgar a cristianos viejos de manera que, hasta inicios del siglo XVIII, el $60 \%$ de sus sentencias pronunciadas ya no afectaron a judíos, moriscos y protestantes. Desde este conocimiento estadístico del banco de datos establecido por Henningsen los historiadores han podido sorprenderse de que la Inquisición dejara de ser un ins-

31 Contreras y Henningsen (1986, pp. 100-129). En realidad, al poco, resultaron ser 44674 las causas. 
trumento de persecución de minorías religiosas para ir transformándose en el aparato ideológico del Estado moderno español para formación de la nación.

Sorprende su agudeza crítica en un artículo de finales 80 sobre la relevancia de los estudios sobre la Inquisición (Henningsen, 1988, pp. 35-51). En él hace balance de la dirección emprendida tras el boom de los 70 por los estudiosos españoles de la Inquisición (Pérez Villanueva, Escandell y Bonet, García Cárcel, Contreras, etc.) muy centrados en la institución misma y sin abrir pistas micro-históricas al estilo Leroi-Ladurie o Ginzburg. Y para advertir de que es preciso tomar críticamente el documento, aparte de señalar algunos caveat, cita de ese historiador italiano lo paradójico del valor documental: «La falta de comunicación entre interrogado e inquisidor representa para nosotros la garantía de la autenticidad de la fuente. Cuando el inquisidor no entiende lo que el reo le explica, tenemos nosotros la oportunidad de comunicación directa con el pasado». Una paradoja de la que él mismo intentó escapar en el caso de las acusaciones de brujería en Navarra.

Las características de esa «base de datos», iniciada a mano en los 70 y recientemente informatizada merced a dos colaboradores, G. Knutsen (Universidad de Bergen) y M. Drelichman (Universidad de Columbia), las describió con cuadros y mapas en The Database of the Spanish Inquisition (Henningsen, 1993, pp. 43-85). Henningsen guarda «coleccionadas» para sí más de dos mil de estas causas, fotocopiadas a fin de poder ir dibujando una especie de biografías mágicas. En base a esos documentos y en su entusiasmo por los relatos de Caro Baroja en Vidas mágicas e Inquisición, continúa escribiendo conforme saca tiempo singulares casos del «universo mágico» que tan fuerte le tiene enganchado como folklorista ${ }^{32}$.

Así es como desde Henningsen acá, merced a su encendido asombro ante la realidad que produce en él una tan rara como endiablada intuición, cierto pasado no se halla colocado en un pedestal museístico sino que se nos ha hecho más extraño a fin de que podamos inspeccionarlo desde nuevas perspectivas. Yo le admiro a él tanto como él admira a nuestro maestro don Julio.

He hablado mucho con Gustav y Marisa, ¡Hermanos!, y os diré que he encontrado gran humanidad en su mucha grandeza

\section{LISTA DE REFERENCIAS}

Azurmendi, M. (1995). La invención de la brujería como aquelarre. Bitarte, 7, 15-38. Azurmendi, M. (2010). La brujería vasco-navarra y el colapso cultural de los perseguidos (1609-1612). En E. Ramalle y M. Azurmendi, Inquisición y Brujería.

32 Citaré dos: un ritual de naipes en Granada junto con un proceso contra cinco hechiceras (Henningsen, 2014). Y otro en colaboración con J. Escribano: el de una hechicera labortana sirviente en Arrigorriaga (Henningsen, 2013, pp. 87-94). 
El auto de fe de Logroño de 1610 (pp. 33-74). Logroño: Instituto de Estudios Riojanos.

Caro Baroja, J. (1969). De nuevo sobre la historia de la brujería (1609-1619). Príncipe de Viana, 30, 741-802.

Caro Baroja, J. (1974). De nuevo sobre la historia de la brujería (1609-1619). Inquisición, brujería y criptojudaísmo. Barcelona: Ariel.

Caro Baroja, J. (1986). El ballet del inquisidor y la bruja. La Inquisición. Historia 16, extra 1, 66-74.

Contreras, J. \& Henningsen, G. (1986). Forty-Four Thousand Cases of the Spanish Inquisition (1540-1700). Analysis of a Historical Data Bank. En G. Henningsen \& J. Tedeschi, The Inquisition in Early Modern Europe. Studies on Sources and Methods (pp. 100-129). Dekalb: Northern Illinois University. Henningsen, G. (1958). Albatrosser, klabautermænd og anden sømandstro. Berlingske Tidende 19-07-1958.

Henningsen, G. (1959b). Vedel og Syv og bogtrykkerne. En bibliografisk undersøgelseaf af Hundredvisebogen. Danske studier, 53-84.

Henningsen, G. (1960). Skipper historier. Skibet. Dansk Søfart, 11, 19-20.

Henningsen, G., Holbek, B. \& Rasmussen, H. (1960, 1963-1964). Bibliografi over Dansk Folkekultur. København: Foreningen Danmarks Folkeminder.

Henningsen, G. (1961). Kunsten at lyve lodret. Staffens løjeri Himmerland, Vestfold-Minne, 64-99.

Henningsen, G. (1965a). The Art of Perpendicular Lying. Concerning a Commercial Collection of Norwegian Sailors. Tall Tales. Journal of the Folklore Institute, 2, 180-219.

Henningsen, G. (1965b). Cuentos marineros. Revista de Etnografia, 7, 39-48.

Henningsen, G. (1969). Trolddom og hemmelige kunster. En A. Steensberg (ed.), Dagligliv i Danmark 1629-1720 (pp. 161-196, 727-731). København: Nyt Nordisk Forlag.

Henningsen, G. (1969). Rapport fra et studieophold i Spanien. Nordnynt, 34, 20-31.

Henningsen, G. (1971). Informe sobre tres años de investigaciones etnológicas en España. Ethnica. Revista de antropología, 1, 61-90.

Henningsen, G. (1977). El banco de datos del Santo Oficio. Las relaciones de causas de la Inquisición española. Boletín de la Real Academia de la Historia, 124, 547-570.

Henningsen, G. (1978). Alonso de Salazar Frías. Ese famoso inquisidor desconocido. En Homenaje a Julio Caro Baroja (pp. 81-586). Madrid: CIS.

Henningsen, G. (1979). Las víctimas de Zugarramurdi. El origen de un gran proceso de brujería. Saioak. Revista de estudios vascos, 2, 182-195.

Henningsen, G. (1980a). The Greatest Witch-Trial of All: Navarra, 1609-14. History Today, 30, 36-39.

Henningsen, G. (1980b). The Witches' Advocate. Basque Witchcraft and the Spanish Inquisition. Reno: University of Nevada.

Henningsen, G. (1982). El mayor proceso de la historia: Navarra, 1609-1614. Historia $16,7,46-54$.

Henningsen, G. (1983). El abogado de las brujas. Brujería vasca e inquisición española. Madrid: Alianza editorial. 
Henningsen, G. (1988). ¿Por qué estudiar la Inquisición? Reflexiones sobre historiografía reciente y el futuro de una disciplina. Manuscript, 7, 35-51.

Henningsen, G. (1990). The Ladies from Outsid. An Archaïc Pattern of the Witches'Sabbath. En B. Ankarloo \& G. Henningsen Early Modern European Witchcraft. Centres and Peripheries. Oxford: Clarendon.

Henningsen, G. (1991-1992). The White Sabbath and Other Archaic Patterns of Witchcraft. Acta Ethnographica Academiae scientiarum Hungaricae, 37, 293304.

Henningsen, G. (1993). The Database of the Spanish Inquisition. The «relaciones de causas» Project revisited. En H. Mohnhaupt, D. Simon (eds.), Vorträge zur Justizforschung. Geschichte und Theorie (pp. 43-85). Frankfurt am Main: Max Planck Institut für Europäische Rechtsgeschichte.

Henningsen, G. (1995). The Cateschism of Witchlore in 20th Century Denmark. XI congreso de la International Society for Folk Narrative Research (1995, january 6-12, Mysore, India).

Henningsen, G. (1995). El estudio de la brujería y la opinión pública. Bitarte, 7, 5-14.

Henningsen, G. (1996a). Barnhäxor för och nu. Signum, 22, 79-84.

Henningsen, G. (1996b). The child witch syndrome. Satanic child abuse of today and witch-trials of yesterday. The Journal of Forensic Psychiatry, 7, 581-593.

Henningsen, G. (1998). La inquisición y las brujas. En L'Inquisizione, Atti del Simposio internazionale (pp. 567-605). Cittá del Vaticano: Biblioteca Apostólica Vaticana.

Henningsen, G. (2001). El invento de la palabra aquelarre. En J. M. Usunáriz Garayoa (ed.). Historia y Humanismo. Estudios en honor del profesor Dr. D. Valentín Vázquez de Prada (vol. 1, pp. 351-359). Pamplona: EUNSA.

Henningsen, G. (2004). The Salazar Documents. Inquisitor Alonso de Salazar Frías and Others on the Basque Witch Persecution. Leiden-Boston: Brill.

Henningsen, G. (2010). Andanzas por España de un inquisidor a la moderna de raza nórdica. Huarte de San Juan. Geografía e Historia, 17, 423-441.

Henningsen, G. (2013). Inquisición y ciencia. La suerte de la olla. Huarte de San Juan, Geografía e Historia, 20, 87-94.

Henningsen, G. (2014). Los inquisidores de Llerena y el universo mágico del sur. Inquisición, XV Jornadas de Historia en Llerena (pp. 31-46). Llerena: Sociedad Extremeña de Historia.

Henningsen, G. (2015). Fotografías etnográficas 1965-1968. Galicia máxica. Reportaxe dun mundo desaparecido. Santiago: Museo do Povo Galego.

Lisón Tolosana, C. (1969). Límites simbólicos. Apuntes sobre la parroquia rural en Galicia. Revista española de la Opinión Pública, 15, 101-151.

Lisón Tolosana, C. (1976). Antropología social en España. Madrid: Akal.

Rey-Henningsen, M. (1994). The World of the Ploughwoman. Folklore and Reality in Matriarchal Northwest Spain. Helsinki: Akademia Scientarum Fennica. 